\title{
Implementasi Sistem Konfirmasi Pembayaran Pinjaman pada Koperasi Simpan Pinjam Berbasis Android
}

\author{
Eka Adhitya Dharmawan
}

\begin{abstract}
Abstrak-Koperasi simpan pinjam adalah merupakan koperasi yang meningkatkan kesejahteraan anggotanya dengan kegiatan kredit berbunga rendah. Namum ada kalannya terdapat kendala-kendala yang terjadi terlebih dalam proses penagihan dan pembayaran. Salah satunya adalah kerap terdapat kecurangan yang dilakukan oleh petugas penagihan yang berasal dari koperasi itu sendiri. Permasalahan manajemen penagihan dan konfirmasi dapat diatasi dengan membuat suatu sistem yang membantu proses verifikasi pembayaran yang menjembatani anggota yang melakukan peminjaman dengan data peminjam yang terdapat di pusat penyimpanan data anggota. Dalam hal ini keberadaan android sebagai perangkat mobile yang relatif mudah dan terjangkau dapat dimanfaatkan sebagai platform sistem. Melalui proses enkripsi "tanggal lahir +4 digit di belakang ktp" dapat menjadi pin yang akan dipakai untuk melakukan konfirmasi pembayaran. Aplikasi Konfirmasi Pembayaran dapat membantu pengelola koperasi dalam mengatasi masalah manajemen penagihan, karena selain dapat membantu mempermudah pengerjaan penagihan, mengatasi human error serta aplikasi dimaksud juga dapat meminimalisir terjadinya kecurangan baik dari pihak yang memiliki hutang maupun pihak kurir sebagai penanggung jawab penagihan.
\end{abstract}

Kata Kunci-Koperasi Simpan Pinjam, Penagihan, Konfirmasi, Kurir, Android

\section{Pendahuluan}

$\mathrm{K}$ operasi merupakan suatu bentuk usaha yang bertujuan untuk meningkatkan pertumbuhan ekonomi masyarakat yang berlandaskan azas kekeluargaan, sehingga dalam melakukan kegiatan koperasi mengutamakan kesejahteraan anggotanya [7]. Ada beberapa jenis koperasi yang berkembang di Indonesia, salah satunya adalah koperasi impan pinjam. Rudianto menjelaskan koperasi simpan pinjam adalah Koperasi yang kegiatannya untuk menghimpun dana dan menyalurkan melalui kegiatan simpan pinjam dari dan untuk anggota koperasi yang bersangkutan, calon anggota koperasi yang bersangkutan,koperasi lain dan atau anggotanya.

Sedangkan menurut Burhanuddin, koperasi simpan pinjam adalah koperasi yang didirikan guna memberikan kesempatan kepada para anggotanya untuk memperoleh pinjaman atas dasar kebaikan. Koperasi simpan pinjam adalah merupakan koperasi

Eka A Dharmawan adalah pengajar di program studi Teknik Informatika Jurusan Teknik Elektro Politeknik Negeri Ambon email: eadpolnam@gmail.com yang meningkatkan kesejahteraan anggotanya dengan kegiatan kredit berbunga rendah [8].

Sesuai dengan tujuan pendiriannya, keberadaan koperasi simpan pinjam sangat mebantu anggotanya dalam meninggkatkan kesejahteraan terlebih dalam hal ekonomi. Dalam perjalanannya aktifitas pinjam meminjam pada koperasi berjalan sesuai dengn anggaran dasar dan anggaran rumah tangga. Namum ada kalannya terdapat kendala-kendala yang terjadi terlebih dalam proses penagihan dan pembayaran. Salah satunya adalah kerap terdapat kecurangan yang dilakukan oleh petugas penagihan yang berasal dari koperasi itu sendiri. Sering terjadi di dalam proses penagihan seorang petugas yang ditugaskan tersebut dapat melakukan hal-hal yang tidak terpuji yaitu seperti penipuan, dimana saat para peminjam sudah membayarkan cicilan mereka secara rutin pada petugas/penagih, tetapi setelah penagih mendapatkan uang dari peminjam, uang itu kemudian dipakai untuk kepentingan dirinya sendiri. Kemudian karena uang dari hasil tagihan tersebut sudah digunakan oleh petugas tersebut maka petugas akan memberikan pernyataan palsu yaitu mengatakan bahwa petugas tersebut belum mendapatkan pembayaran dari peminjam.

Pada dasarnya proses konfirmasi yang dilakukan saat proses pembayaran hutang antara client yang meminjam uang dengan kurir yang ditugaskan untuk menagih hutang. Dan koperasi simpan pinjam adalah suatu tempat dimana semua orang dapat meminjam uang dengan cicilan yang ditentukan sesuai dengan uang yang dipinjam di tempat tersebut, dan jika peminjam sudah mendapatkan uang pinjaman, maka akan di tentukan tanggal tagihan yang harus dibayar rutin untuk menutupi cicilan dari uang pinjaman yang dipinjam pada koperasi. Kemudian pada saat penagihan cicilan, maka ada seorang petugas yang ditugaskan langsung dari koperasi tersebut untuk datang ke rumah peminjam yang mengambil uang pinjaman pada koperasi tersebut untuk mengambil uang cicilan dari peminjam tersebut.

Permasalahan tersebut diatas dapat diatasi dengan membuat suatu sistem yang membantu proses verifikasi pembayaran yang menjembatani anggota yang melakukan peminjaman dengan data peminjam yang terdapat di pusat penyimpanan data anggota. Dalam hal ini keberadaan android sebagai perangkat mobile yang relatif mudah dan terjangkau dapat dimanfaatkan sebagai platform sistem.

Berdasarkan penjabaran tersebut ditas maka penulis mengambil suatu penelitian tentang Implementasi 
Sistem Pembayaran Pinjaman Pada Koperasi Simpan Pinjam Berbasis Android. Penelitian dimaksud diharapkan dapat mengurangi tingkat human error maupun kecurangan-kecurangan yang dapat dilakukan petugas dalam mengumpulkan icilan dari para anggota peminjam.

\section{TINJAUAN PUSTAKA}

\section{A. Konfirmasi}

Konfirmasi atau confirmation yaitu komunikasi tertulis kepada pihak lain atau mitra yang menjelaskan hal-hal relevan secara terperinci tentang transaksi. Istilah konfirmasi bila ditinjau dari segi Etimologi (bahasa) berasal dari bahasa inggris confirm atau confirmation yang berarti menguatkan, penguatan atau pengesahan. Sedangkan konfirmasi dari segi istilah diantaranya yaitu konfirmasi akan memperteguh hubungan interpersonal. Konfirmasi juga untuk memperteguh hubungan interpersonal antara pengusaha dan calon pelanggan. Dalam mengonfirmasi keputusan pelanggan diperlukan suatu komunikasi bisnis yang efektif [2].

\section{B. Android}

Android adalah sistem operasi berbasis Linux yang dirancang untuk perangkat bergerak sentuh seperti telepon pintar dan komputer tablet. Android awalnya dikembangkan oleh Android, Inc., dengan dukungan finansial dari Google, yang kemudian membelinya pada tahun 2005. Android adalah sistem operasi dengan sumber terbuka, dan Google merilis kodenya di bawah Lisensi Apache. Kode dengan sumber terbuka dan lisensi perizinan pada Android memungkinkan perangkat lunak untuk dimodifikasi secara bebas dan didistribusikan oleh para pembuat perangkat, operator nirkabel, dan pengembang aplikasi [1]. Selain itu, Android memiliki sejumlah besar komunitas pengembang aplikasi (apps) yang memperluas fungsionalitas perangkat, umumnya ditulis dalam versi kustomisasi bahasa pemrograman Java. Android juga menjadi pilihan bagi perusahaan teknologi yang menginginkan sistem operasi berbiaya rendah, bisa dikustomisasi, dan ringan untuk perangkat berteknologi tinggi tanpa harus mengembangkannya dari awal. Sifat Android yang terbuka juga telah mendorong munculnya sejumlah besar komunitas pengembang aplikasi untuk menggunakan kode sumber terbuka sebagai dasar proyek pembuatan aplikasi, dengan menambahkan fiturfitur baru bagi pengguna tingkat lanjut atau mengoperasikan Android pada perangkat yang secara resmi dirilis dengan menggunakan sistem operasi lain.

\section{PIN (personal identification number)}

Nomor Identifikasi Pribadi (personal identification number) diucapkan "PIN" merupakan angka sandi rahasia antara pengguna dan sistem yang dapat digunakan untuk otentikasi pengguna ke sistem. Biasanya, pengguna diharuskan untuk memberikan identifikasi pengguna umum atau bukti dan PIN rahasia untuk mendapatkan akses ke sistem. Setelah menerima
User ID dan PIN, sistem melihat PIN didasarkan pada User ID dan membandingkan PIN pada sistem dengan PIN yang diterima. Pengguna mendapatkan akses hanya bila nomor yang dimasukkan sesuai dengan nomor yang disimpan dalam sistem [4].

\section{Client-Server}

Client-server adalah suatu bentuk arsitektur, dimana client adalah perangkat yang menerima yang akan menampilkan dan menjalankan aplikasi (software komputer) dan server adalah perangkat yang menyediakan dan bertindak sebagai pengelola aplikasi, data, dan keamanannya. Server biasanya terhubung dengan client melalui kabel UTP dan sebuah kartu jaringan (network card). Kartu jaringan ini biasanya berupa kartu PCI atau ISA. Dalam teknologi informasi, client-server merujuk kepada cara mendistribusikan aplikasi ke pihak client dan pihak server. Dalam model client-server, sebuah aplikasi dibagi menjadi dua bagian yang terpisah (tetapi masih dalam sebuah kesatuan) yakni komponen client dan komponen server.

Komponen client dijalankan pada sebuah workstation. Pemakai workstation memasukkan data dengan menggunakan teknologi pemrosesan tertentu, kemudian mengirimkannya ke komponen server, umumnya berupa permintaan layanan tertentu yang dimiliki oleh server. Komponen server akan menerima permintaan layanan tersebut dan langsung memprosesnya serta mengembalikan hasil pemrosesan kepada client. Client pun menerima informasi hasil pemrosesan data tadi dan menampilkannya kepada pemakai dengan menggunakan aplikasi yang digunakan oleh pemakai.

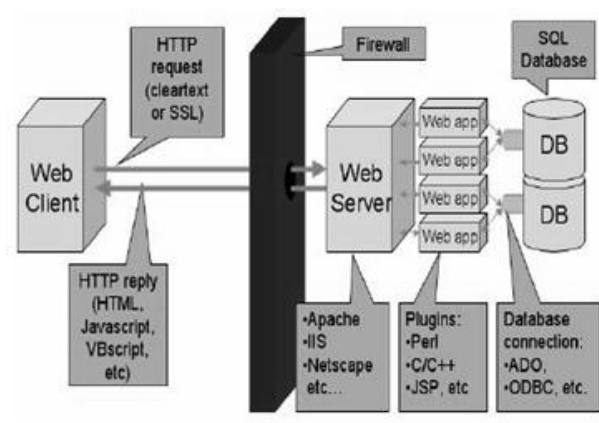

Gambar1 . Contoh Komponen Aplikasi Web[3].

\section{E. PHP}

PHP adalah singkatan dari "PHP: Hypertext Prepocessor", yaitu bahasa pemrograman yang digunakan secara luas untuk penanganan pembuatan dan pengembangan sebuah situs web dan bisa digunakan bersamaan dengan HTML. PHP diciptakan oleh Rasmus Lerdorf pertama kali tahun 1994. Pada awalnya PHP adalah singkatan dari "Personal Home Page Tools". SelYanjutnya diganti menjadi FI ("Forms Interpreter"). Sejak versi 3.0, nama bahasa ini diubah menjadi "PHP: Hypertext Prepocessor" dengan singkatannya "PHP". PHP versi terbaru adalah versi ke-5. Berdasarkan survey Netcraft pada bulan Desember 1999, lebih dari sejuta website menggunakan PHP, di antaranya adalah NASA, 
Mitsubishi, dan RedHat.

\section{F. $J D K$ (Java Development Kit)}

JDK adalah Perangkat lunak yang digunakan untuk melakukan proses kompilasi dari kode java ke bytecode yang dapat dimengerti dan dapat dijalankan oleh JRE (Java Runtime Envirotment)[9]. JDK wajib terinstall pada komputer yang akan melakukan proses pembuatan aplikasi berbasis java, namun tidak wajib terinstall di komputer yang akan menjalankan aplikasi yang dibangun dengan java.

\section{G. HTML (Hypertext Markup Language)}

Hypertext Markup Language (HTML) adalah sebuah bahasa markah yang digunakan untuk membuat sebuah halaman web, menampilkan berbagai informasi di dalam sebuah penjelajah web Internet dan pemformatan hiperteks sederhana yang ditulis dalam berkas format ASCII agar dapat menghasilkan tampilan wujud yang terintegerasi. Dengan kata lain, berkas yang dibuat dalam perangkat lunak pengolah kata dan disimpan dalam format ASCII normal sehingga menjadi halaman web dengan perintah-perintah HTML. Bermula dari sebuah bahasa yang sebelumnya banyak digunakan di dunia penerbitan dan percetakan yang disebut dengan SGML (Standard Generalized Markup Language), HTML adalah sebuah standar yang digunakan secara luas untuk menampilkan halaman web. HTML saat ini merupakan standar Internet yang didefinisikan dan dikendalikan penggunaannya oleh World Wide Web Consortium (W3C). HTML dibuat oleh kolaborasi Caillau TIM dengan Berners-lee Robert ketika mereka bekerja di CERN pada tahun 1989 (CERN adalah lembaga penelitian fisika energi tinggi di Jenewa).

\section{H. XAMPP}

XAMPP ('zæmp/ atau /'eks.æmp/) adalah perangkat lunak bebas, yang mendukung banyak sistem operasi, merupakan kompilasi dari beberapa program. Fungsinya adalah sebagai server yang berdiri sendiri (localhost), yang terdiri atas program Apache HTTP Server, MySQL database, dan penerjemah bahasa yang ditulis dengan bahasa pemrograman PHP dan Perl. Nama XAMPP merupakan singkatan dari $\mathrm{X}$ (empat sistem operasi apapun), Apache, MySQL, PHP dan Perl. Program ini tersedia dalam GNU General Public License dan bebas, merupakan web server yang mudah digunakan yang dapat melayani tampilan halaman web yang dinamis. Untuk mendapatkanya dapat mendownload langsung dari web resminya[6].

\section{Ionic Framework}

Ionic adalah sebuah framework aplikasi mobile berbasis HTML5 yang dapat digunakan untuk mengembangkan apikasi mobile dengan teknologi web seperti HTML, CSS, dan Javascript. Dengan menggunakan Ionic, para developer web bisa membuat aplikasi lintas platform seperti untuk Android dan iOS. Dengan menggunakan Ionic, para developer web tidak perlu belajar bahasa pemrograman Java, Objective C, atau C\# untuk membuat aplikasi mobile karena mereka cukup menggunakan ilmu mereka di bahasa pemrograman web.

Ionic mempunyai kelebihan diantaranya bersifat open source dan juga menggunakan teknologi web terbaru. Ionic juga menggunakan Angular JS untuk implementasi logic-nya. Kabarnya, dengan menggunakan Angular JS aplikasi yang dibuat menggunakan Ionic akan dapat berjalan sangat cepat seperti halnya aplikasi native. Untuk desain tampilan antarmuka aplikasi, ini dimudahkan di Ionic dengan bantuan ID-nya yang bernama Ionic Lab. Ini berbeda dengan framewok lain seperti jQuery Mobile di mana harus di buat koding manual untuk membuat tampilan antarmuka aplikasinya.

\section{Metode PenElitian}

\section{A. Metode Penelitian}

Metode yang digunakan dalam menyelesaikan penelitian adalah metode Research dan Development (riset dan Pengembangan), yaitu suatu metode yang dipakai untuk mengembangkan model, alat atau aplikasi tertentu berdasarkan proses penelitian.

\section{B. Analisis Masalah}

Berdasarkan latar belakang diatas maka analisis masalah yang pakai adalah "Bagaimana caranya agar pada saat proses penagihan antara petugas dan peminjam bisa diketahui oleh pimpinan pada koperasi dimaksud".

\section{Teknik Pengambilan Data}

Pada penelitian ini penulis melakukan beberapa teknik pengambilan data, diantaranya adalah

a) Observasi :

Yaitu dengan cara melakukan pengamatan secara langsung tentang pelaksanaan sistem yang sedang berjalan.

b) Wawancara :

Yaitu bertanya langsung kepada pihak yang mempunyai kepentingan dan terlibat langsung dalam sistem pinjam dan tagih di koperasi simpan pinjam.

c) Studi Literatur :

Mempelajari atau mengunjungi situs-situs yang berhubungan dengan sistem yang sedang dibangun.

\section{Sumber Data}

Sumber data yang penulis peroleh dari berbagai macam sumber yaitu koperasi-koperasi yang ada didalam kota ambon. Untuk menjadi referensi untuk membuat aplikasi ini dan juga untuk mengetahui statistik keuangan pada masing-masing koperasi simpan pinjam yang ada di kota ambon, agar bisa dipakai untuk menambah pengetahuan bagi penulis agar bisa membuat aplikasi ini menjadi lebih baik dalam hal Keamanan, karena dengan mengetahui proses dan cara kerja dari koperasi dan statistic keuangan koperasi tersebut, maka penulis bisa memakai data-data tersebut untuk digunakan sebagai referensi untuk membuat aplikasi ini agar bisa mengatasi masalah yang sudah dijelaskan pada latar belakang diatas. 


\section{E. Perancangan Sistem}

Perancangan Sistem akan menjelaskan jalannya alur sistem dalam penelitian. Perancangan sistem dapat dijelaskan melalui diagram alir data.

1. Data Flow Diagram (DFD)

Data flow diagram ini adalah diagram dikomposisikan/penjabaran dari diagram, konteks, yang menjadi alur penyimpanan data peminjam dan proses enkripsi "tanggal lahir +4 digit di belakang ktp" menjadi pin yang akan dipakai untuk melakukan konfirmasi pembayaran pada proses pembayaran yang terjadi antara peminjam dan kurir yang ditugaskan dari koperasi untuk menagih hutang pada masing-masing peminjam yang meminjam uang pada koperasi simpan pinjam.. DFD dapat dilihat pada gambar 2

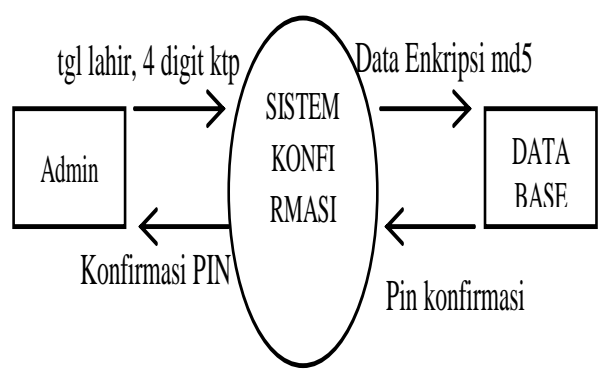

Gambar 2. Data Flow Diagram (DFD)

Terdapat 2 entitas luar yakni Admin dan Data Base, dengan fungsi masing-masing yakni Admin berlaku untuk menginputkan data kedalam sistem dan Database sebagai media penyimpan dta yang akan dipergunakan untuk mengkonfirmasi data yang diinputkan..

2. Flowchart

Flowchart sistem yang merupakan penjelasan bergambar atas jalannya sistem konfirmasi pembayaran dari peminjam. Penjelasan Flowchart pada gambar 3. Proses diawali dengan Login yang dilakukan oleh peminjam, Selanjutnya akan ada pengecekan pada sistem apakah user sudah melakukan registrasi atau belum. Jika sudah maka proses akan dilanjutkan dengan menu transaksi, namun jika beum maka user akan dihantarkan pada menu registrasi terlebih dahulu. Setelah transaksi maka akan ada menu terima pembayara, untuk selanjutnya user tinggal memilih melakukan pembayaran atau membatalkannya.

\section{HASIL DAN PEMBAHASAN}

Setelah dilakukan analisa dan perancangan maka dapat ditampilkan hasil randang bangun aplikasi untuk konfirmasi peminjaman di koperasi simpan pinjam. Adapun hasil seperti gambar 4. Tampilan awal berupa menu utama ataupun yang disebut tampilan beranda memuat menu profil, transaksi dan Logout.

Pada gambar 5 tampilan transaksi terdapat menu Terima Pembayaran dimana menu ini dipakai untuk memasukan data pada proses transaksi nanti. Yang didalamnya ada terima pembayaran, yang digunakan untuk memasukan data untuk di kirim ke server, yaitu

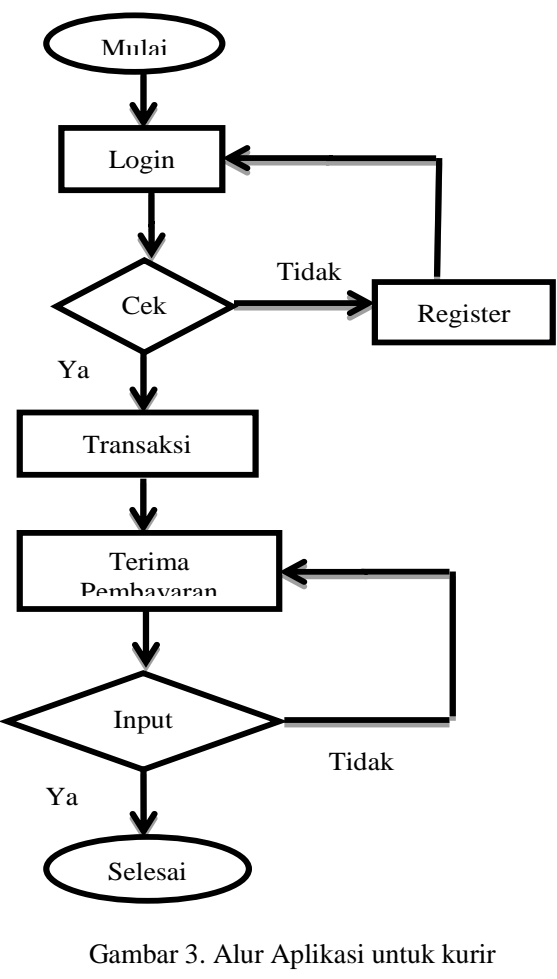

nama peminjam, pin
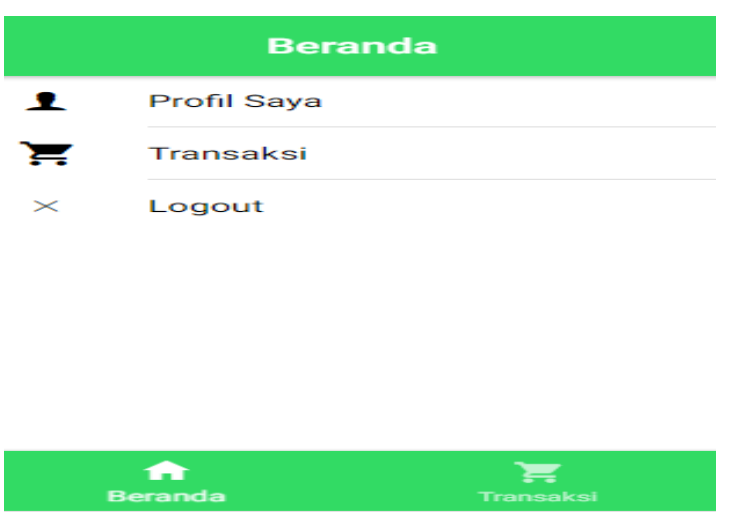

Gambar 4. Tampilan Beranda
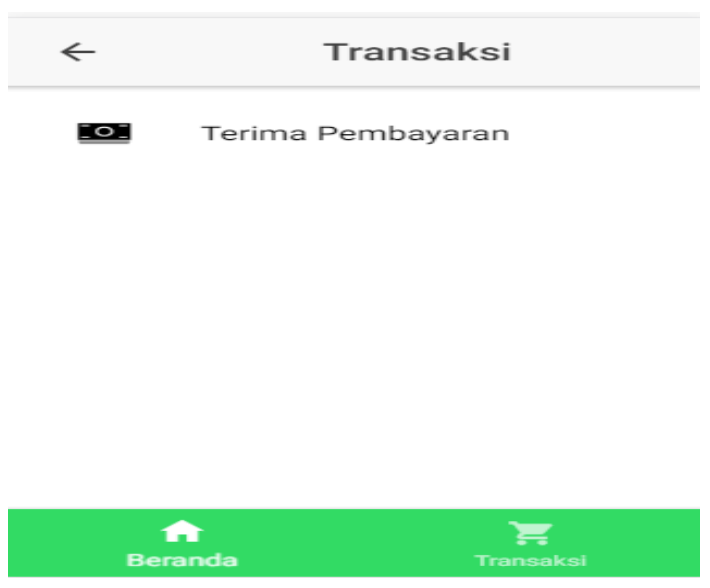

Gambar 5. Menu Transaksi 
peminjam, jumlah pinjaman, dan tanggal pembayaran, dengan begitu maka secara otomatis data yang diisi akan dikirim ke database server.

Berdasarkan gambar 6, pada tampilan terima pembayaran terdapat beberapa daftar yang harus diisi berdasarkan data yang akan diambil dari peminjam yaitu Nama Peminjam, Pin Peminjam (yang akan dipakai untuk konfirmasi pembayaran dan pin tersebut akan menjadi bukti bahwa peminjam telah membayar cicilan dan terdaftar di dalam database server koperasi. Dengan demikian data yang sudah tersimpan di dalam database server akan terlihat oleh admin koperasi simpan pinjam.

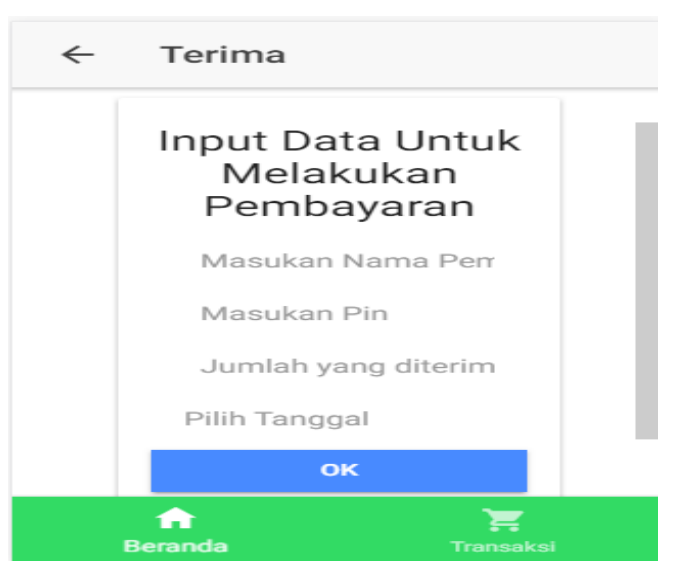

Gambar 6. Menu Terima Pembayaran

Pada Form tersebut dapat terlihat menu-menu untuk memasukkan data peminjam, pin yang telah dirancang sebelumnya, jumlah transaksi yang dibayarkan serta tanggal transaksi dilakukan.

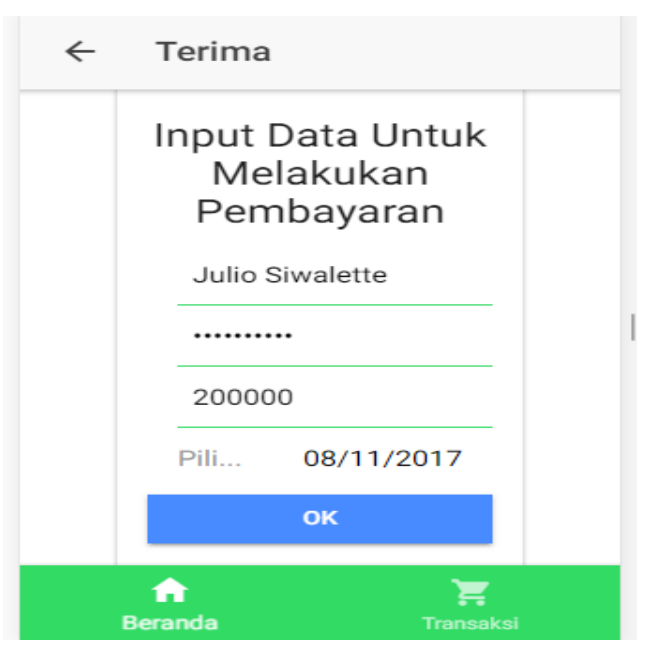

Gambar 7. Contoh Form Pengisian Data

Data-data yang diisi akan dikirimkan sebagai bukti pembayaran antara peminjam dan kurir yang ditugaskan dari koperasi sebagai penagih. Pada gambar dapat dilihat bahwa telah dibuat input text dari pin dengan menggunakan type password dimana agar Pin konfirmasi tersebut tidak bisa diketahui oleh kurir, karena dengan pin itu maka dapat diketahui kebenaran pada proses pembayaran yang dilakukan antara peminjam dengan kurir yang ditugaskan untuk menagih hutang pada peminjam yang meminjam uang pada koperasi simpan pinjam. Untuk itu sangat disarankan bagi pelanggan untuk tidak membagikan PIN yang dimiiki kepada sembarangan orang untuk mencegah terjadinya kecurangan-kecurangan pada sistem pembayaran.

\section{KESIMPULAN DAN SARAN}

\section{A. Kesimpulan}

Setelah melakukan observasi, perancangan dan pengimplementasian maka dapat diambil kesimpulan bahwa Aplikasi Konfirmasi Pembayaran dapat membantu pengelola koperasi dalam mengatasi masalah manajemen penagihan, karena selain dapat membantu mempermudah pengerjaan penagihan, mengatasi human error serta aplikasi dimaksud juga dapat meminimalisir terjadinya kecurangan baik dari pihak yang memiliki hutang maupun pihak kurir sebagai penanggung jawab penagihan, karena dilengkapi dengan pengamanan sistem berupa konfigurasi PIN dalam mengakses sistem konfirmasinya.

\section{B. Saran}

Diharapkan pengembangan sistem kedepan dapat ditambahkan fitur-fitur pengaman yang lebih ketat baik berupa enkripsi yang lebiih berjenjang, dan dapat pula ditambahkan tampilan menu yang memungkinkan koneksi langsung antara pihak manajemen koperasi dengan para anggota yang melakukan peminjaman.

\section{DAFTAR PUSTAKA}

[1] Adelheid A., dan Aqilha S., 2012. Manual Book of Android. Jogjakarta: Litera Media Creativa. ISBN: 978602-18836-4-8

[2] Arek Indo, 2016, Pengertian Konfirmasi dan Diskonfirmasi https://arekindo.blogspot.co.id/2014/06/pengertiankonfirmasi-dan-diskonfirmasi.html Diakses pada tanggal 15 Oktober 2017

[3] Rahardjo B. 1999. Keamanan Sistem Informasi Berbasis Internet. PT Insan Komunikasi. Bandung.

[4] Budiarto, 2001, Press Tool 1, Politeknik Manufaktur Bandung, Bandung.

[5] Griffin, Ricky. E. 1999. Management. Edisi kelima, New Jersey.

[6] Fathansyah, Ir. 1999. Basis Data. Penerbit Informatika. Bandung.

[7] Latifah, N.P. 2006. Akuntansi Untuk Koperasi Simpan Pinjam atau Unit Simpan Pinjam (Accounting for load save cooperation or loan save unit), Jurnal Fokus Ekonomi, Vol. 1 No. 1 Juni 2006: 63,80.

[8] Suyanto, dan Nurhadi, 2003, IPS Ekonomi, Penerbit Erlangga, Yogyakarta.

[9] Wicaksono, Adi. 2002. Dasar-dasar Pemrograman Java 2. Elex Media Kompuntindo. Jakarta. 